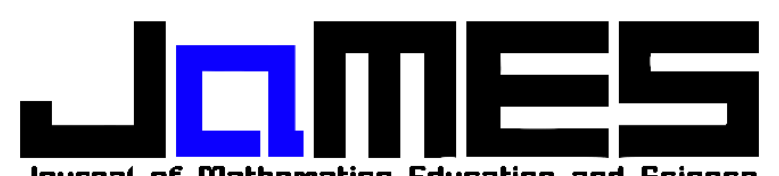

Juurnal of Mathematics Education and Science

VOL. 3 NO. 2 (2020) : 55-60

p-ISSN: 2621-1203 | https://doi.org/10.32665/james.v3i2.138 | e-ISSN: 2621-1211

\title{
MENINGKATKAN KEMAMPUAN BERPIKIR KREATIF MATEMATIS MELALUI MODEL PEMBELAJARAN EXPERIENTIAL LEARNING BERBASIS ZONE OF PROXIMAL DEVELOPMENT (ZPD)
}

\author{
Roby Firdian Ruswanda ${ }^{1}$, Achi Rinaldi ${ }^{2}$, Siska Andriani ${ }^{3}$, Gusti Ayu Farah Nabilla ${ }^{4}$ \\ Universitas Islam Negeri Raden Intan Lampung, Robyfirdianr@gmail.com ${ }^{1}$ \\ Universitas Islam Negeri Raden Intan Lampung, Achi@ radenintan.ac.id ${ }^{2}$ \\ Universitas Islam Negeri Raden Intan Lampung, Siskaandriani@ radenintan.ac.id ${ }^{3}$ \\ Universitas Islam Negeri Raden Intan Lampung, Gustiayufarahnabilla@gmail.com ${ }^{4}$ \\ Received: 26 Mei 2020, Revised : 26 Agustus 2020, Accepted : 30 Oktober 2020
}

(C) Mathematics Education Unugiri 2020

\begin{abstract}
This research's background is the students' mathematical creative thinking abilities that are rarely of concern so that they are generally classified as low. This study aims to determine the Zone of Proximal Development Experiential Learning model's effect based on improving mathematical creative thinking skills. The design of this study uses the Quasi-Experimental Design form. This study's population were students of class VII SMP Negeri 19 Bandar Lampung with a sample of two experimental classes and one control class. Data analysis used the One Way Anova test, and the significance level was 5\%. Based on the average increase, the Experiential Learning Model, based on the Zone of Proximal Development, is as good as the Experiential Learning Model. The Experimental Learning Model is based on Zone Of Proximal Development is better with conventional learning, Experiential Learning Model is better with conventional learning.
\end{abstract}

Keywords: Mathematical creative thinking, Experiential Learning, Zone Of Proximal Development.

\begin{abstract}
Abstrak
Latar belakang penelitian ini adalah kemampuan berpikir kreatif matematis peserta didik yang jarang menjadi perhatian sehingga secara umum masih tergolong rendah. Tujuan dari penelitian ini mengetahui pengaruh model pembelajaran Experiential Learning berbasis Zone Of Proximal Development untuk meningkatkan kemampuan berpikir kreatif matematis. Desain penelitian ini menggunakan bentuk Quasi Experimental Disign. Populasi pada penelitian ini yaitu siswa kelas VII SMP Negeri 19 Bandar Lampung dengan sampel dua kelas eksperimen dan satu kelas kontrol. Analisis data menggunakan uji One Way Anova dan taraf signifikan 5\%. Berdasarkan rata - rata peningkatan disimpulkan bahwa Model pembelajaran Experiential Learning berbasis Zone Of Proximal Development sama baiknya dengan Model pembelajaran Experiential Learning, Model pembelajaran Experiential Learning berbasis Zone Of Proximal Development lebih baik dengan pembelajaran konvensional, Model pembelajaran Experiential Learning lebih baik dengan pembelajaran konvensional.
\end{abstract}

Kata kunci: Berpikir kreatif matematis, Experiential Learning, Zone Of Proximal Development

\section{Pendahuluan}

Matematika adalah mata pelajaran yang melatih kemampuan berpikir dan bernalar, mengembangkan aktivitas kreatif, mengembangkan kemampuan pemecahan masalah dan mengkomunikasikan gagasan [1]. Kemampuan berpikir ada beberapa macam salah satunya adalah berpikir kreatif. Berpikir kreatif dianggap penting karenanya apabila kemampuan 
berpikir kreatif rendah maka berimplikasi pada rendahnya prestasi. Menurut Wahyudin kemampuan berpikir kreatif dapat membuat seseorang memiliki fleksibilitas yaitu mencari alternatif lain dalam menyelesaikan suatu masalah [2]. Hal tersebut sesuai dengan pernyataan munandar bahwa pada beberapa kasus sekolah cenderung menghambat kreativitas dengan mengembangkan kekakuan imajinasi. dikarenakan kurangnya perhatian terhadap masalah kreativitas dan penggaliannya khususnya dalam matematika [3]. Permasalahan mengenai kurangnya kemampuan berpikir kreatif matematis salah satunya peneliti temukan pada peserta didik SMP Negeri 19 Bandar Lampung. Peneliti melakukan uji kemampuan berpikir kreatif atau pra-penelitian pada kelas VII I sebagai sampel tentang kemampuan berpikir kreatif peserta didik terhadap materi sistem persamaan linier satu variabel. Hasil prapenelitian tersaji pada tabel 1 sebagai berikut ini:

Tabel 1.Hasil Tes Kemampuan Berpikir Kreatif Matematis

\begin{tabular}{ccccc}
\multicolumn{4}{c}{ Matematis } \\
\cline { 3 - 4 } Kelas & \multirow{2}{*}{ KKM } & \multicolumn{2}{c}{ Hasil Belajar } & Peserta \\
\cline { 3 - 4 } & & $\begin{array}{c}\mathbf{X}< \\
\mathbf{7 0}\end{array}$ & $\begin{array}{c}\mathbf{X} \geq \\
\text { didik }\end{array}$ \\
\hline VII I & 70 & 26 & 5 & 31
\end{tabular}

Sumber: Daftar Nilai Tes VIII ajaran 2018/2019

Penelitian ini relevan dengan penelitian
yang dilakukan terdahulu. Model
pembelajaran Experiential Learning telah
diteliti oleh Andy Sapta yang menyatakan
model Experiential Learning dapat meningkatkan komunikasi matematis peserta didik. Sejalan dengan hal tersebut Sugeng Utaya dan Singgih Susilo menyatakan bahwa model Experiential Learning dapat mempengaruhi kemampuan berpikir peserta didik.

Kemampuan berpikir kreatif disebabkan oleh faktor lain yang mempengaruhinya yaitu kemampuan pemecahan masalah. Maka perlu diterapkannya pembelajaran yang dapat membuat peserta didik lebih aktif serta memiliki semangat untuk belajar, mendorong peserta didik membuat konsepnya sendiri dari materi yang telah disampaikan pendidik. Pemilihan model pembelajaran dianggap sentral dalam proses belajar guna menentukan ketercapaian rencana pelaksanaan pembelajaran.

Model pembelajaran Experiential Learning berbasis Zone of Proximal Development menjadi salah satu alternatif pilihan pada proses pembelajaran. Model pembelajaran Experiential Learning adalah model pembelajaran yang menkankan pengalaman peserta didik sebagai katalisator dalam pembelajaran.

Pelaksanaan model Experiential Learning memiliki empat tahapan. Pertama pengalaman konkrit (Concrete Experience), pada tahap ini peserta didik diberikan stimulus yang membuat peserta didik mengerjakan suatu aktivitas dalam bentuk kegiatan. Kegiatan ini didasarkan pada pengalaman peserta didik sebelumnya baik formal maupun informal atau situasi yang nyata. Dilaksanakan dalam atau luar kelas dan dikerjakan oleh perseorangan atau kelompok. Kedua observasi refleksi (Reflection Observation), pada tahap ini peserta didik mengamati pengalaman dari kegiatan yang dilakukan dengan menggunakan panca indra atau media. Selanjutnya peserta didik merefleksikan pengalamannya.

Ketiga konseptualisasi abastrak (Abstract Conseptualizion), pada tahap ini peserta didik mengonseptualisasi konsep dari pengalaman yang diperoleh dan mengintegrasikan dengan pengalaman sebelumnya. Keempat eksperimentasi aktif(Active Experimentation), pada tahap ini peserta didik mencoba merencanakan bagaimana menguji kemampuan konsep untuk menjelaskan pengalaman baru yang akan diperoleh selanjutnya. Pengalaman sebelumnya dapat diterapkan pada situasi problematika atau pengalaman yang baru diperoleh peserta didik [4]. 
Menurut [5] model pembelajaran Experiential Learning dapat mengaktifkan proses pembelajaran karena pengalaman peserta didik menjadi dasar pembelajaran sehingga peserta didik terlibat langsung dengan proses pembelajaran bukan hanya memberikan ilmu oleh pendidik ke peserta didik [6]. Sejalan dengan pendapat Sugeng Utaya, Andy Sapta berpendapat bahwa Model ini memberikan kebebasan berekspresi pada peserta didik, saat peserta didik bingung dan tidak mengerti maka akan mencari alternatif penyelesaian dari masalah yang diberikan. Sehingga peserta didik akan antusias berdiskusi dengan kelompoknya [7].

Selanjutnya model pembelajaran Experiential Learning dibasiskan dengan Zone Of Proximal Development, menurut Adi Nur Cahyono Zone Of Proximal Development adalah zona antara tingkat perkembangan actual dan tingkat perkembangan potensial. Tingkat perkembangan actual tampak dari kemampuan peserta didik menyelesaikan tugas - tugas secara mandiri. Sedangkan tingkat perkembangan potensial tampak dari kemampuan peserta didik menyelesaikan tugas atau memecahkan masalah dengan bantuan [8].

Menurut Stufy dalam Sugeng Sutiarso Zone Of Proximal Development adalah daerah antara apa yang dilakukan peserta didik sendiri pada actual development level (tingkat perkembangan saat ini) yaitu kemampuan peserta didik dalam memecahkan masalah dan apa yang dicapai peserta didik tersebut untuk potencial development (tingkat perkembangan potensial) yang merupakan kemampuan peserta didik dalam memecahkan masalah bila dibantu oleh orang dewasa atau ahli [6].

Berdasarkan penjelasan yang telah diuraikan peneliti, model pembelajaran Experiential Learning berbasis Zone of
Proximal Development diharapkan dapat menghasilkan dampak positif terhadap peningkatan kemampuan berpikir kreatif. Keterbaruan dalam penelitian ini terletak pada model pembelajaran Experiential Learning yang didasari Zone Of Proximal Development

\section{Metode Penelitian}

Metode penelitian menggunakan Quasi Eksperimental Design [9]. Penelitian ini mempunyai dua variabel yaitu varibel bebas (independent variable) dan variabel terikat (dependent variable). Desain pada penelitian menggunakan Nonequivalent Control Group Design tersaji pada tabel berikut [10]:

Tabel 2. Desain Penelitian

\begin{tabular}{cccc}
\hline Kelompok & Pretest & Treatment & Postest \\
\hline Eksperimen1 & $o_{1}$ & Y & $o_{2}$ \\
\hline Eksperimen2 & $o_{3}$ & X & $o_{4}$ \\
\hline Kontrol & $o_{5}$ & - & $o_{6}$ \\
\hline
\end{tabular}

Keterangan:

$\boldsymbol{o}_{\mathbf{1}}$ : Pretest kemampuan berpikir kreatif matematis kelompok eksperimen 1

$\boldsymbol{o}_{2}$ : Postest kemampuan berpikir kreatif matematis kelompok eksperimen 1

$\boldsymbol{o}_{\mathbf{3}}$ : Pretest kemampuan berpikir kreatif matematis kelompok eksperimen2 $\boldsymbol{o}_{\mathbf{4}}$ : Postest kemampuan berpikir kreatif matematis kelompok eksperimen2

$\boldsymbol{o}_{\mathbf{5}}$ : Pretest kemampuan berpikir kreatif matematis kelompok kontrol

$\boldsymbol{o}_{6}$ : Postest kemampuan berpikir kreatif matematis kelompok kontrol

Y : Pembelajaran dengan menggunakan model Experiential Learning

$\mathbf{X}$ : Pembelajaran dengan menggunakan model pembelajaran Experiential Learning berbasis Zone Of Proximal Development

Populasi penelitian yaitu seluruh peserta didik kelas VII SMP Negeri 19 Bandar Lampung tahun pelajaran 2019/2020. Teknik sampling menggunakan Cluster Random Sampling [11]. Teknik pengumpulan data yang digunakan berupa tes, wawancara serta dokumentasi. Teknik 
analisis data yang digunakan adalah uji homogenitas jenis Bartlett yang digunakan untuk menguji sampel yang homogen, uji normalitas jenis Kolmogorov-Smirnov digunakan untuk mengetahui berdistribusi normal atau tidaknya sampel, uji hipotesis jenis One Away Anova digunakan untuk menarik jawaban, uji N-gain dilakukan guna mengetahui besarnya peningkatan kemampuan berpikir kreatif peserta didik dan uji Schaffe yaitu uji pasca anava untuk mengetahui perbedaan perlakuan.

\section{Hasil dan Pembahasan}

Penelitian ini dilaksanakan di SMP Negeri 19 Bandar Lampung dengan sampel sebanyak tiga kelas, meliputi kelas VII F yang menjadi eksperimen1 dan diberikan treatment model pembelajaran Experiential learning, kelas VII E menjadi eksperimen2 dan diberikan treatment model pembelajaran Experiential learning berbasis zone of proximal development dan kelas VII $\mathrm{K}$ sebagai kelas kontrol melalui model pembelajaran konvensional. Sebelum di berikan treatment pada setiap kelas dilakukan tes awal atau pretest guna mengetahui kemampuan awal berpikir kreatif peserta didik pada materi aritmatika sosial dengan hasil sebagai berikut:

Tabel 3. Deskripsi Data Hasil Pretest Kemampuan Berpikir Kreatif Matematis

\begin{tabular}{lccccc}
\hline \multirow{2}{*}{ Kelompok } & \multirow{2}{*}{$\boldsymbol{x}_{\max }$} & $\boldsymbol{x}_{\boldsymbol{m i n}}$ & \multicolumn{3}{c}{ Ukuran Tendensi } \\
\cline { 3 - 6 } & & & $\overline{\boldsymbol{x}}$ & $\boldsymbol{M}_{\boldsymbol{o}}$ & $\boldsymbol{M}_{\boldsymbol{e}}$ \\
\hline Eksperimen1 & \multirow{2}{*}{17,3} & 5,3 & 10,4 & 6,6 & 10,6 \\
\hline Eksperimen2 & 18,7 & 5,3 & 10,5 & 6,6 & 9,3 \\
\hline Kontrol & 17,3 & 4 & 10 & 6,6 & 9,3 \\
\hline
\end{tabular}

Dapat dilihat dari Tabel 3 diatas bahwa nilai tertinggi untuk kelas eksperimen1 sebesar 17,3 dan eksperimen2 sebesar 18,7 lalu untuk kelas kontrol sebesar 17,3. Nilai terendah pada kelas eksperimen1 yaitu 5,33 dan untuk kelas eksperimen2 sebesar 5,33 lalu untuk kelas kontrol sebesar 4. Ukuran tendensi sentral pada kelas ekperimen 1 dengan rata - rata 10,41 dan nilai yang sering muncul adalah 6,66 lalu nilai tengahnya sebesar 10,66 lalu untuk kelas eksperimen 2 rata - rata 10,58 dan nilai yang sering muncul adalah 6,66 dan nilai tengahnya sebesar 9,33 sedangkan pada kelas kontrol dengan rata - rata 10,06 dan nilai yang sering muncul adalah 6,66 lalu nilai tengahnya sebesar 9,33.

Selanjutnya setelah dilakukan prestest maka diterapakan treatment pada masing masing kelas. Setelah selesai diterapkannya treatment perlu dilaksanakan tes akhir atau posttest guna mengetahui sejauh mana treatment berperan untuk meningkatkan kemampuan berpikir kreatif matematis dan hasil sebagai berikut ini:

Tabel 4. Deskripsi Data Hasil Postest Kemampuan Berpikir Kreatif Matematis

\begin{tabular}{cccccc}
\hline & & \multicolumn{4}{c}{ Ukuran } \\
Kelompok & $\boldsymbol{x}_{\max }$ & $\boldsymbol{x}_{\boldsymbol{m i n}}$ & \multicolumn{4}{c}{ Tendensi Sentral } \\
\cline { 3 - 6 } & & & $\overline{\boldsymbol{x}}$ & $\boldsymbol{M}_{\boldsymbol{o}}$ & $\boldsymbol{M}_{\boldsymbol{e}}$ \\
\hline Eksperimen1 & \multirow{2}{*}{90,6} & 53,3 & 66,7 & 60 & 64 \\
& & & & \\
\hline Eksperimen2 & 86,6 & 50,6 & 68,1 & 64 & 64 \\
\hline Kontrol & 70,6 & 50,6 & 59,8 & 50,6 & 60 \\
\hline
\end{tabular}

Dapat dilihat dari Tabel 4 diatas bahwa nilai tertinggi untuk kelas eksperimen1 sebesar 90,66 dan eksperimen2 sebesar 86,66 lalu untuk kelas kontrol yaitu 70,66. Nilai terendah pada kelas eksperimen1 yaitu 53,33 dan untuk kelas eksperimen2 sebesar 50,66 lalu untuk kelas kontrol sebesar 50,66. Ukuran tendensi sentral pada kelas ekperimen1 dengan rata rata 66,70 dan nilai yang sering muncul adalah 60 lalu nilai tengahnya sebesar 64 lalu untuk kelas eksperimen2 rata - rata 68,12 dan nilai yang sering muncul adalah 64 dan nilai tengahnya sebesar 64 pada kelas kontrol memiliki rataan 59,86 serta nilai yang sering muncul adalah 50,66 lalu nilai tengahnya sebesar 60. Untuk mengetahui 
sebesar mana peningkatan melalui uji $\mathrm{N}$ gain melalui data pretest dan postest yang telah didapat hasilnya tersaji sebagai berikut:

Tabel 5. Deskripsi Data N-Gain Kemampuan Berpikir Kreatif Matematis

\begin{tabular}{cccccc}
\hline \multirow{2}{*}{ Kelompok } & \multirow{2}{*}{$\boldsymbol{x}_{\max }$} & $\boldsymbol{x}_{\boldsymbol{m i n}}$ & \multicolumn{4}{c}{$\begin{array}{c}\text { Ukuran Tendensi } \\
\text { Sentral }\end{array}$} \\
\cline { 3 - 6 } & & & $\overline{\boldsymbol{x}}$ & $\boldsymbol{M}_{\boldsymbol{o}}$ & $\boldsymbol{M}_{\boldsymbol{e}}$ \\
\hline Eksperimen1 & 0,8 & 0,4 & 0,6 & 0,5 & 0,6 \\
& & & & & \\
\hline Eksperimen2 & 0,8 & 0,4 & 0,6 & 0,4 & 0,6 \\
& & & & & \\
\hline Kontrol & 0,4 & 0,6 & 0,5 & 0,4 & 0,5 \\
\hline
\end{tabular}

Dapat dilihat dari Tabel 5 diatas bahwa nilai tertinggi pada kelompok eksperimen1 yaitu 0,89 serta eksperimen2 yaitu 0,85 lalu pada kelompok kontrol sebesar 0,41 . Nilai terendah pada kelompok eksperimen1 sebesar 0,48 serta untuk kelompok eksperimen2 sebesar 0,64 lalu untuk kelompok kontrol yaitu 0,55. Ukuran tendensi sentral pada kelompok ekperimen 1 dengan rata - rata 0,62 dan nilai yang sering muncul adalah 0,51 lalu nilai tengahnya sebesar 0,61 lalu untuk kelas eksperimen2 rata - rata 0,64 dan nilai yang sering muncul adalah 0,47 dan nilai tengahnya yaitu 0,60 pada kelompok kontrol dengan rata - rata 0,55 dan nilai yang sering muncul adalah 0,44 lalu nilai tengahnya sebesar 0,54 .

Selanjutnya dilakukan uji komparasi ganda menggunakan SPSS dan dianalisis menggunakan uji hopotesis pertama $\left(\mu_{1} v s \mu_{2}\right)$ didapatkan nilai sebesar 0,890 sehingga $0,890>0,05$ berarti $H_{0}$ diterima serta $H_{1}$ ditolak, sehingga tidak ada perbedaan signifikan antara kelas eksperimen1 dengan kelas eksperimen2. Hasil uji hipotesis kedua $\left(\mu_{1} v s \mu_{2}\right)$ didapatkan nilai sebesar 0,041 sehingga $0,041<0,05$ berarti $H_{0}$ ditolak serta $H_{1}$ diterima, sehingga ada perbedaan sinifikan antara kelas eksperimen1 dengan kontrol. Hasil uji hipotesis ketiga $\left(\mu_{2} v s \mu_{3}\right)$ didapatkan nilai 0,012 berarti $0,012<0,05$ sehingga $H_{0}$ ditolak serta $H_{1}$ diterima, berarti terdapat perbedaan yang signifikan pada kelas eksperimen2 dengan kontrol. Proses pembelajaran Experiential Learning maupun konvensional berjalan sangat baik hanya saja, pada kelas konvensional peserta didik kurang antusias dan pasif ketika kegiatan pembelajaran berlangsung.

\section{Penutup}

Berdasarkan hasil analisis data, uji hipotesis serta pembahasan yang telah dijabarkan dan penulis dapat menyimpulkan peningkatan kemampuan berpikir kreatif melalui model pembelajaran Experiential Learning berbasis Zone of Proximal Development sama dengan model pembelajaran Experiential Learning, peningkatan kemampuan berpikir kreatif melalui model pembelajaran Experiential Learning berbasis Zone of Proximal Development lebih besar dari pada melalui model pembelajaran konvensional, peningkatan kemampuan berpikir kreatif melalui model pembelajaran Experiential Learning lebih besar dari pada melalui model pembelajaran konvensional.

\section{Referensi}

[1] Siswono, Tatag Yuli Eko. "Upaya Meningkatkan Kemampuan Berpikir Kreatif Siswa Melalui Pengajuan Masalah.” Jurnal Pendidikan Matematika Dan Sains Vol. 1 No. 10 (2005): Hal. 3.

[2] Rahman, Riski. "Hubungan Antara SelfConcept Terhadap Matematika Dengan Kemampuan Berpikir Kreatif Matematik Siswa." Infinity Journal 1 No. 1 (2012): Hal. 20.

[3] Munandar. Pengembangan Kreativitas Anak Berbakat. Jakarta: Rineka Cipta, 2004.

[4] A Kolb, David. "Experiential Learning Theory: Previous Research And New Directions." Department of Organizational Behavior. 
[5] Utaya, Sugeng. "Pengaruh Model Experiential Learning Terhadap Kemampuan Berpikir Siswa Sma." Jurnal Pendidikan: Teori,Penelitian Dan Pengembangan Vol. 1, No. 11 (2016): Hal. 2097.

[6] Sutiarso, Sugeng. "Scafollding Dalam Pembelajaran Matematika." Prosiding Seminar Nasional Penelitian, Pendidikan Dan Penerapan Mipa, 2009, Hal.2.

[7] Sapta, Andy. "Pengaruh Model Pembelajaran Experiential Learning Terhadap Komunikasi Matematis Siswa." Pythagoras: Jurnal Pendidikan Matematika Vol. 6, No. 2 (2017): Hal. 98.

[8] Nur Cahyono, Adi. "Vygotskian Perspective: Proses Scaffolding Untuk Mencapai Zone Of Proximal Development(ZPD) Peserta Didik Dalam Pembelajaran Matematika." Seminar Nasional Matematika Dan Pendidikan Matematika Yogyakarta 2010 (27 November): Hal. 443-444.

[9] Rinaldi, Achi. "Pengaruh Pembelajaran Berbantuan Geogebra Terhadap Pemahaman Konsep Matematis Ditinjau Dari Gaya Kognitif." Al-Jabar Jurnal Pendidikan Matematika Vol. 7, No.1 (2016): Hal. 118.

[10] Darmani, Jamroni Wibi, Dan Achi Renaldi. "Analisis Kemampuan Pemecahan Masalah Matematis: Dampak Model Pembelajran Reciprocal Teaching Dengan Fieldtrip.” Desimal: Jurnal Matematika 1no. 3 (2018).

[11] Susanto, Hery, Achi Rinaldi, Dan Novalia. "Analisis Validitas Reliabilitas Tingkat Kesukaran Dan Daya Beda Pada Butir Soal Ujian Akhir Semester Ganjil Mata Pelajaran Matematika Kels XII IPS Di SMA Negeri 12 Bandar Lampung." Al - Jabar: Jurnal Pendidikan Matematika 6 No. 2 (2015): 207 